Mr IGOR ŠĆEPANOVIĆ, pilot-potpukovnik

Uprava za planiranje i razvoj Generalštab Vojske Srbije

Beograd, Neznanog junaka 38

UDK 341.79(594.75)"2002/2004"

$355.357(497.1) " 2002 / 2004 "$

\title{
UNMISET $^{1}$ - PRVO ANGAŽOVANJE SAVEZNE REPUBLIKE JUGOSLAVIJE U MULTINACIONALNIM OPERACIJAMA
}

\begin{abstract}
APSTRAKT: Delovanje Ujedinjenih nacija u Istočnom Timoru predstavlja jedan od malobrojnih slučajeva sveobuhvatnog delovanja subjekata međunarodne zajednice, od stvaranja državnosti do rešavanja konflikta. Članak daje kratak istorijat sukoba u Istočnom Timoru koji je doveo do uspostavljanja jedne od misija UN u Istočnom Timoru - UNMISET. Ukratko su prikazani rad te misije, rezultati ali i slabosti tokom delovanja. Zbog značaja ove misije za Saveznu Republiku Jugoslaviju odnosno Državnu zajednicu Srbije i Crne Gore, kao prve misije UN u kojoj su angažovani vojni kapaciteti tadašnje države, posle raspada SFRJ, u članku je dat kratak pregled angažovanja pripadnika tadašnje Vojske Jugoslavije, odnosno Vojske Srbije i Crne Gore. ${ }^{2}$
\end{abstract}

Ključne reči: Istočni Timor, Portugal, Indonezija, Australija, kolonijalizam, Ujedinjene nacije, vojni posmatrači UN, INTERFET, UNTAET, UNMISET, koncept neostarateljstva

\section{Istorija sukoba u Istočnom Timoru}

Sukob u Istočnom Timoru se proteže kroz više istorijskih perioda. Portugal je kolonizovao Istočni Timor 1515. godine, kada su se prvi Portugalci iskrcali na ostrvo. U narednim stolećima portugalska kolonijalna vlast se postepeno širila iz centara za trgovačku razmenu, da bi obuhvatila celo ostrvo pred kraj XIX veka. Proces kolonizacije nije tekao glatko i zabeleženo je više značajnijih sukoba u kojima se stanovništvo pokušalo odupreti

${ }^{1}$ Misija podrške Ujedinjenih nacija u Istočnom Timoru (United Nations Mission of Support in East Timor - UNMISET).

${ }^{2}$ Tokom angažovanja prve rotacije vojnih posmatrača, država Savezna Republika Jugoslavija je promenila naziv u Državna zajednica Srbije i Crne Gore. 
kolonizaciji. ${ }^{3}$ Kolonijalna vlast je trajala sve do sredine 70 -ih godina prošlog veka uprkos stalnom nastojanju Ujedinjenih nacija da primoraju Portugal da izvrši dekolonizaciju, odnosno da pripremi svoju koloniju na samostalnost. Portugal to nije uradio i 1974. godine, posle „Karanfilske revolucije“ $u$ Portugalu, kojom je označen slom portugalskog kolonijalnog carstva, Istočni Timor se našao potpuno nepripremljen da preuzme vlastitu sudbinu $u$ svoje ruke. Sa druge strane, Indonezija, koje je i sama bila holandska kolonija do 1948. godine, gajila je pretenzije prema Istočnom Timoru, smatrajući da ima prirodno pravo na taj deo arhipelaga kojim bi zaokružila vlastitu teritorijalnu celinu.

Istočni Timor je u vreme raspada kolonijalnog portugalskog carstva bio podeljen načelno oko tri ideje oko kojih su se formirale i tri glavne političke partije:

Narodna demokratska asocijacija Timora (Associacão Popular Democratica Timorense - APODETI), koja je pozivala na integraciju sa Indonezijom, osnovana 1974;

Socijaldemokratska asocijacija Timora (Associação Social-Democrata Timorense-ASDT $)^{4}$, zalagala se za nezavisnost;

Demokratska unija Timora (União Democrática Timorense - UDT), zalagala se za federaciju sa Portugalom i rešavanje statusa kroz postepeni proces.

Između ove tri partije izbio je kratkotrajni građanski rat avgusta 1975, u kome je pobedu odnela ASDT, odnosno opcija nezavisnosti i samostalnosti. S obzirom na njen marksistički predznak, ${ }^{5}$ izostala je široka podrška ovoj partiji, kao i priznanje samostalnosti koju je Istočni Timor objavio u novembru 1975. godine. Umesto priznanja samostalnosti, 7. decembra 1975. usledila je invazija i aneksija od strane Indonezi-

${ }^{3}$ Za vreme kolonijalne vlasti zabeleženi su u više navrata sukobi između Istočnotimoraca i portugalske vlasti. Najznačajniji od njih su: sukob kod Kova Lime (Cova Lima) 1719. godine; sukob kod Kova-Kotubabe (Cova-Cotubaba) 1868-1869; Manufahi ratovi 1895-1912; pobuna stanovništva u distriktu Vikiki 1959. godine.

${ }^{4}$ ASDT je vrlo brzo promenila ime u Revolucionarni front za nezavisni Istočni Timor (Frente Revolucionaria de Timor Leste Indipendente - FRETILIN), a odmah posle kratkotrajnog građanskog rata 1975. godine, osniva i svoje vojno krilo - Oružane snage za nacionalno oslobođenje Istočnog Timora (Forças Armadas de Libertação Nacional de Timor Leste FALINTIL).

${ }^{5}$ Ideje kojima se napajao antikolonijalni pokret u Istočnom Timoru svoje korene su imale u idejama ostalih oslobodilačkih pokreta portugalskog kolonijalnog carstva, a njihov predznak je bio marksistički. Treba se podsetiti da je prva polovina 70 -ih godina prošlog veka bila u znaku rata u Vijetnamu i straha zapadnog sveta od širenja komunizma u region jugozapadne Azije. Stoga nijedan marksistički pokret nije mogao imati značajnu podršku zapadnog bloka, koji je dominirao tim regionom, posebno posle „demontiranja“ Komunističke partije Indonezije krajem 60-ih godina prošlog veka. 
je, uz tajnu podršku $\mathrm{SAD}^{6}$ i to samo dan posle posete predsednika SAD Indoneziji. $^{7}$

Otpor invaziji i okupaciji trajao je u kontinuitetu, a njegov nosilac je bio FRETILIN na političkom međunarodnom polju, dok je oružanu borbu vodio FALINTIL. Borba protiv indonežanske okupacije je različitim intenzitetom vođena sve do 1991. godine, bez značajnije podrške svetske javnosti ili uticajnih država. Jedina podrška je dolazila od strane Portugala, koji je uspeo da pitanje Istočnog Timora održi „u životu“ u UN. Prekretnicu u nastojanjima Istočnotimoraca da se izbore za pravo na samoopredeljenje predstavlja masakr od strane indonežanskih snaga, nakon demonstracija u glavnom gradu Diliju, kod groblja katedrale Santa Kruž, gde je na brutalan način ubijena 271 osoba, ranjeno 280, a 270 osoba je vođeno kao „nestali“. Posle kraja Hladnog rata, međunarodna zajednica je napokon postala osetljiva na ugrožavanje ljudskih prava, i nakon ovog događaja pokrenut je dugotrajan proces pregovaranja Indonezije i Portugala pod okriljem UN, o rešavanju statusa Istočnog Timora.

Pregovarački proces je doveo do dogovora o organizaciji svenarodnog izjašnjavanja naroda Istočnog Timora, koji je i realizovan početkom septembra 1999, u vrlo nepovoljnim bezbednosnim uslovima i uz porast nasilja. Nasilje je eruptiralo posle proglašenja rezultata izjašnjavanja gde je oko $75 \%$ glasača izašlih na glasanje izabralo samostalnost. Proindonežanske milicije, uz indirektnu, a ponegde i direktnu pomoć regularnih indonežanskih snaga potpuno su uništile infrastrukturu Istočnog Timora, izvršile veći broj ubistava, a više od polovine stanovništva naterale u zbegove. Glavni razlog ovolikom nasilju predstavljao je strah Indonezije da i neke druge regije unutar države ne krenu istim putem, a nasilje je predstavljalo poruku da to ne čine.

Vrlo brzo posle izbijanja nasilja, Indonezija je pristala da prihvati multinacionalne vojne snage INTERFET (International Forces East Timor) ${ }^{8}$ koje su na brzinu formirane od država regiona, na čelu sa Australijom i uz brojno učešće Portugala. Zadatak tih snaga je bio da, preko operacije pod

${ }^{6}$ Andrea K. Molnar, East Timor: An Introduction To The History, Politics And Culture Of Southeast Asia's Youngest Nation, Northern Illinois University, Department of Anthropology and Center for Southeast Asian Studies, May 2005.

7 Memorandum o razgovoru predsednika SAD Forda, predsednika Indonezije Suharta, državnog sekretara Kisindžera, ministra spoljnih poslova Indonezije Malika, državnog ministra Sudharmona i ambasadora SAD u Indoneziji Njusoma 6. decembra 1975. National Archives, Record Group 59, Department of State Records, Transcripts of Staff Meetings of Secretary of State Henry Kissinger, 1973-77, box 8, George Washington University, http://www.gwu.edu/ nsarchiv/NSAEBB/NSAEBB62/

${ }^{8}$ Martin Ian, Mayer-Rieckh Alexander, The United Nations and East Timor: From Self-determination to State-Building, International Peacekeeping, Vol. 12, No. 1, proleće 2005, 125-145. 
nazivom „Stabilizuj“ (Stabilise), uspostave bezbedno okruženje radi normalizacije humanitarne situacije u Istočnom Timoru. Indonežanske snage su ubrzo napustile Istočni Timor, a skupština Indonezije je priznala rezultate referenduma u Istočnom Timoru već 19. oktobra 1999. godine. Iako su neposredno pre sukoba u Istočnom Timoru bile angažovane u sličnoj operaciji, SAD nisu neposredno učestvovale u operaciji u ovoj oblasti, upravo objašnjavajući svoj izostanak iscrpljenošću prethodnom „humanitarnom intervencijom" na Balkanu, u Saveznoj Republici Jugoslaviji. ${ }^{9}$

\section{Angažovanje UN u Istočnom Timoru}

Stabilizacijom humanitarne situacije u Istočnom Timoru, Ujedinjene nacije su se susrele sa problemom potpunog odsustva organizovane države usled čega su bile primorane da obrazuju institucije sposobne za donošenje novih zakona i preuzmu ulogu vođenja države. Štaviše, nakon povlačenja indonežanskih snaga prestalo je funkcionisanje svih tehničkih službi koje omogućuju postojanje državnog ustrojstva. Ujedinjene nacije su pri upravljanju Istočnim Timorom u početku imale karakter „starateljskog saveta" (Trusteeship Council). Ovakva praksa je u radovima pojedinih autora i dobila naziv „neostarateljstvo“. ${ }^{10}$

Na osnovu rezolucije Saveta bezbednosti UN 1272 od 25. oktobra

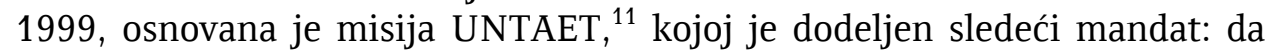
osigura bezbednost i održava red i zakon na celoj teritoriji Istočnog Timora; uspostavi efikasnu administraciju; pomogne u razvoju građanskih i socijalnih službi; osigura koordinaciju i dostavu humanitarne pomoći, obnovu i pomoć u razvoju; podrži razvoj kapaciteta za samoupravu Istočnog Timora; pomogne u uspostavljanju uslova za održivi razvoj.

Tokom svog trajanja UNTAET je vršio razne aktivnosti radi ispunjenja svog mandata. Vrlo brzo se vratila većina izbeglica iz Zapadnog Timora, odnosno Indonezije, kao i interno raseljena lica u mesta prethodnog boravka što je bio najveći humanitarni izazov za misiju. Započeta je izgradnja državnih institucija kroz obnovu sudova i njihovog rada, ${ }^{12}$ osnivanje univer-

${ }^{9}$ House Report 106-244- Department of Defense Appropriations Bill, 2000. United States Air Force-At a Crossroads? 16. 10. 2004. http://www.thomas.loc.gov/cgi-bin/cpquer$\mathrm{y} /$ ?\&db_id=cp106\&r_n=hr244.106\&sel=TOC_50225\&.

${ }^{10}$ Butler Michael: Peace Enforcement And Statebuilding In East Timor: Neo-Trusteeship Revisited, Department of Government and International Relations, Clark University, 17, http://citation.allacademic.com/meta/p_mla_apa_research_citation/2/5/2/2/4/pages252241/p252241-1.php

${ }^{11}$ United Nations Transitional Administration in East Timor.

${ }^{12}$ Prvo javno suđenje je održano već 12 . maja 2000. u Diliju, a prva presuda doneta 24. avgusta 2000. u istom sudu. 
ziteta (oktobra 2000), policijskog koledža za obuku (marta 2000) i oružanih snaga. ${ }^{13}$ Radi doprinosa unutrašnjoj stabilnosti osnovana je Komisija za utvrđivanje i prihvatanje istine i pomirenje (Comissao de Acolhimento, Verdade e Reconciliacao - CAVR) krajem 2000. godine.

UNTAET je preduzeo niz koraka radi uspostavljanja i razvoja institucija neophodnih za vođenje države. Tako je izvršio registraciju stanovništva radi organizovanja izbora za organe nacionalne vlasti, kao i političkih partija i nezavisnih kandidata za izbore za ustavotvornu skupštinu. Izbori su održani 30. avgusta 2001. i na njima je FRETILIN osvojio 57,3\% glasova. Prva prava vlada sastavljena od 24 ministra izabrana je 20. septembra 2001, a prvi ustav je proglašen 22. marta 2002. Na kraju mandata UNTAET-a održani su 14. aprila 2002. predsednički izbori na kojima je pobedio Šanana Gužmao sa 82,7\% glasova nasuprot protivkandidata Franciska do Amarala.

UNTAET je demobilisao FALINTIL stvorivši od dela boraca jezgro budućih oružanih snaga Istočnog Timora. Proces $D^{2} R^{14}$ je u Istočnom Timoru nosio naziv Program pomoći u reintegraciji boraca FALINTIL. ${ }^{15}$ Formirana je i policijska služba, pod nadzorom policijske komponente UNTAET. ${ }^{16}$

Iako je UNTAET imao snažna i široka ovlašćenja, ${ }^{17}$ on nije dao odgovore na sledeće probleme: način ostvarivanja samouprave; odnos i mehanizmi saradnje upravljačke komponente UN prema budućoj vladi Istočnog Timora; mehanizam izjašnjavanja i provođenja volje naroda Istočnog Timora.

Rešavanje ovih problema se pokazalo bitnim posle proglašenja nezavisnosti Istočnog Timora. Nemoć pri njihovom rešavanju ukazala je na strukturne nedostatke same misije UN, kao i na organizacijsku nesavršenost celokupne organizacije UN. ${ }^{18}$ Ipak, može se reći da je celokupna misija

${ }^{13}$ Tranzicioni kabinet je 12. septembra 2009. odobrio osnivanje oružanih snaga jačine do 3.000 pripadnika, uglavnom regrutovanih iz FALINTIL-a.

${ }^{14}$ Razoružanje, demobilizacija i rehabilitacija (Disarmament, Demobilisation and Reintegration - DDR).

${ }^{15}$ FALINTIL Reintegration Assistance Programme (FRAP).

${ }^{16}$ East Timor Police Service - ETPS.

17 „U Istočnom Timoru ne samo da su administrativne funkcije realizovane potpunije nego ikada pre, nego je i telo koje je proisteklo iz intervencije dobilo suverenitet - što je nešto što se nije desilo na međunarodnom nivou od pada Svetog Rimskog Carstva i Vestfalskog sporazuma 1648. godine. U stvari, to je bilo izgrađivanje države kroz uspostavljanje države UN." - Chopra, 'Building state failure in East Timor', Human Rights Quarterly, 25(2), 2003, str. 981.

${ }^{18}$ Razlog ovakvim problemima u velikoj meri leži u dvostrukoj ulozi UNTAET-a koji je zamišljen i kao prelazna administracija i kao organizacija koja treba da razvije kapacitete samog Istočnog Timora potrebne za nezavisnost. Slikovito se to može opisati kao sukob „,logike mirovne operacije” i „logike razvoja”. Razlog ovog „sukoba logika“ leži i u činjenici da je postojala i unutrašnja birokratska borba između Odeljenja za političke poslove 
postigla veliki uspeh i stvorila preduslove za dalji razvoj države Istočnog Timora po proglašenju nezavisnosti 20. maja 2002. ${ }^{19}$

Posle zvaničnog proglašenja nezavisnosti, odnosno državnosti Istočnog Timora 20. maja 2002, razlozi za postojanje misije UN u obliku prelazne administracije su prestali. Država Istočni Timor je morala preuzeti svoje funkcije i odgovornosti na celoj svojoj teritoriji i u svim segmentima države. Naravno, kapaciteti koji su do tog momenta razvijeni bili su nedovoljni za samostalno funkcionisanje bez pomoći UN. Iz tog razloga, Savet bezbednosti UN je rezolucijom 1410 od 17. maja 2002. osnovao novu Misiju UN za podršku Istočnom Timoru (United Nations Mission of Support in East Timor - UNMISET). UNMISET-u je dodeljen sledeći mandat: da obezbedi pomoć administrativnim strukturama ključnim za političku stabilnost Istočnog Timora; obezbedi u prelaznom periodu primenu zakona, javni red i mir i da pomogne u razvoju Policijske službe Istočnog Timora (ETPS); doprinese održavanju spoljne i unutrašnje bezbednosti Istočnog Timora.

Mandat je redovno produžavan do 20. maja 2004. Rezolucijom 1543 SB UN mandat je produžen na još šest meseci sa mogućnošću produženja i na punu godinu dana, do 20. maja 2005. što je i učinjeno rezolucijom SB UN 1573 od 16. novembra 2004. Produženjem mandata istovremeno je smanjena veličina misije, a njen mandat revidiran, saglasno izveštaju generalnog sekretara UN od 29. aprila 2004. i obuhvatio je: podršku javnoj administraciji, pravnom sistemu i sudstvu u rešavanju teških zločina; podršku razvoju sistema primene zakona; podršku bezbednosti i stabilnosti Istočnog Timora.

UNMISET je praktično samo nastavio da funkcioniše kao što je funkcionisao i UNAMET, s tim što je težište pomereno na izgradnju nacije („nation building“) ${ }^{20}$ Bitne razlike su se sastojale u tome što su sve važnije odluke potpisivali zvaničnici Istočnog Timora kao nezavisne države, ali su

(Department of Political Affairs - DPA) i Odeljenja za mirovne operacije (Department of Peacekeeping Operations - DPKO). Vođstvo nad operacijom dato je, neposredno pre početka izvršenja, Odeljenju za mirovne operacije. Problem koji je proizašao iz toga ima korene u institucionalnoj kulturi UNDPKO, odnosno u njegovoj nameni. Naime, UNDPKO jednostavno nije imao sposobnosti da razvije institucije za upravljanje jednom državom, pošto je fokus njegove aktivnosti stvaranje bezbednog okruženja, odnosno rešavanje bezbednosnih problema. - Philpott Simon, East Timor's Double Life: Smells Like Westphalian Spirit, 152.

${ }^{19}$, ,Postojali su uslovi za uspeh kakvi se retko sreću u mirovnim operacijama. Neprijateljske snage su se potpuno povukle, uspostavljene su efikasne multinacionalne snage koje mogu garantovati unutrašnju i spoljnu bezbednost, lokalna populacija je dobrodošlicom dočekala UN i postojao je samo jedan sagovornik - Nacionalni savet otpora Timora (CNRT)." - Chopra Jarat, The UN's Kingdom in East Timor, Survival, Vol. 42, No. 3, jesen 2000, 28.

${ }^{20}$ Ishizuka Katzumi, Peacekeeping in East Timor: the experience of UNMISET, International Peacekeeping, Vol. 10, No. 3, jesen 2003, 44. 
donošene uglavnom u konsenzusu sa UN, odnosno UNMISET. Ugrožavanje bezbednosti vezano za spoljne faktore je već tada bilo bitno smanjeno i osim povremenih incidenata sa bivšim pripadnicima proindonežanskih milicija koji su se pokušavali infiltrirati u dubinu teritorije iz Zapadnog Timora nije bilo drugih bezbednosnih pretnji.

Unutrašnja i spoljna bezbednost, međutim, još uvek su bile u rukama UN. Iako se u misiji nalazio veliki broj iskusnih policajaca iz država bogatih znanjem $\mathrm{u}$ funkcionisanju i obavljanju policijskih poslova, mala važnost je data razvoju policijskih institucija koje bi, u budućnosti, mogle same razvijati policijske snage. To ne znači da su policajci UN isključivo vršili direktne policijske dužnosti, nego su i obučavali pripadnike policije Istočnog Timora PNTL. Razlog relativno lošeg razvoja policije tokom UNMISET-a, pojedini autori objašnjavaju nekorišćenjem iskustava stečenih tokom UNAMET-a zbog institucionalnih trvenja, odnosno rivalstva između Odeljenja za politička pitanja UN koje je organizovalo misiju UNTAET i Odeljenja za mirovne operacije koje je organizovalo misiju UNMISET. ${ }^{21}$ Loše planiranje, kadrovska politika, nedostatak sredstava izazvali su nepoverenje između lokalnog stanovništva i same policije. Vladalo je uverenje da je proces prijema u policijsku službu korumpiran i da se kriterijum prijema zasnivao na rodbinskim vezama. Takođe, regrutovan je relativno veliki broj bivših policajaca POLRI, iz vremena vladavine Indonezije. Poseban problem je bio nedostatak profesionalne kulture, pogotovo onakve kakva vlada u razvijenijim zemljama.

Za razvoj oružanih snaga Istočnog Timora bila je zadužena Kancelarija za razvoj odbrambenih snaga (Office for Defence Force Development ODFD) koja se sastojala od penzionisanih oficira OS SAD, Australije, Velike Britanije, Malezije, Portugala, Tajlanda i još nekih država čiji je zadatak bio planiranje razvoja i savetovanje Visoke komande F-FDTL. Problemi koji su pratili realizaciju ovih aktivnosti su uglavnom bili u komunikaciji vlada angažovanih stranih oficira, vlade Istočnog Timora i rukovodstva misije. Tokom UNTAET mirovne snage su preko ad hoc aranžmana pomagale FFDTL u opremi i uslugama, ali je takav vid saradnje zamro tokom UNMISET.

Kao i u slučaju policije, prijem u F-FDTL je bio prilično kontroverzan. Generalštab F-FDTL je imao praktično odrešene ruke za prijem novih pripadnika oružanih snaga. Jedno od pitanja koje je bitno uticalo na bezbednost Istočnog Timora bilo je odlučivanje ko će biti primljen u F-FDTL, a ko penzionisan kroz program DDR, odnosno FRAP. ${ }^{22}$ Pored pomenutog,

${ }^{21}$ Hood Ludovic, Security Sector Reform In East Timor, 1999-2004, International Peacekeeping, Vol. 13, No. 1, March 2006, 69.

${ }^{22}$ Generalno, FRAP je ocenjen kao dobar i uspešan program, ali mu se zamera da je obuhvatao previše kratak period rehabilitacije i reintegracije u društvo. 
UN su propustile da uspostave svoje ili da razviju kapacitete u društvu za civilnu kontrolu oružanih snaga, tako da skupština i vlada Istočnog Timora jednostavno nisu imale tu mogućnost na raspolaganju. ${ }^{23}$

U odabiru ljudstva veoma je bio primetan uticaj prethodnih sukoba iz vremena FALINTIL-a. Nakon završenog procesa, razne grupe su istupale sa tvrdnjama da registracija nije bila kompletna i to je bio uzrok nezadovoljstva. Te grupe su počele da se pojavljuju tokom 2001. godine i kasnije su postale osnovna pretnja unutrašnjoj bezbednosti Istočnog Timora. Prvi veći sukob posle sticanja državnosti desio se već u novembru 2002. u istočnom delu države, u drugom po veličini gradu - Baukau. Izbijanju nasilja prethodilo je povlačenje mirovnih snaga UNMISET $^{24}$ iz istočnog sektora i predaja nadležnosti i odgovornosti za bezbednost PNTL-u (posebno jedinici specijalne policije koja je potpuno samostalno funkcionisala u gradu Baukau, sa samo nekoliko instruktora iz SAD) i UNPOL. Od snaga UN u tom sektoru ostali su vojni posmatrači, regionalna administrativna kancelarija i policija kao i nevladine organizacije sa i bez mandata UNMISET, što govori da procena bezbednosne situacije nije predviđala njeno bitno narušavanje. Incident je posle nekoliko dana izazvao protestno okupljanje ispred policijske stanice $u$ Baukau koje se pretvorilo u opšti napad i višesatnu opsadu policijske stanice i pokušaj linča pripadnika PNTL. ${ }^{25}$ Situacija je stavljena pod kontrolu dolaskom interventnog voda vojnih snaga UNMISET. Pored neposrednog povoda za nerede $u$ Baukau, dublji razlozi leže $u$ nezadovoljstvu određenih uticajnih pojedinaca i grupa koje se nisu slagale sa novom raspodelom moći u novom društvu i politikom nove elite iz koje su oni bili izostavljeni. ${ }^{26}$

${ }^{23}$ Hood Ludovic, Security Sector Reform In East Timor, 1999-2004, International Peacekeeping, Vol. 13, No. 1, March 2006, 73.

${ }^{24}$ Tajlandski bataljon čija je zona odgovornosti bio istočni sektor napustio je svoju zonu odgovornosti u oktobru 2002.

${ }^{25}$ Incident je nastao pri intervenciji specijalne jedinice ETPS blizu mesta Venilale, da ukloni barikadu na putu koju su postavili meštani sa namerom da naplaćuju prolaz vozilima. Pri pokušaju da se krivci uhapse policija je primenila lično naoružanje tokom čega je ubijen jedan policajac ETPS, ranjeno troje meštana, a ispaljeno je oko 120 metaka, uglavnom kao upozorenje narastajućoj masi da se raziđe. Nekoliko dana posle tog incidenta, održan je protest sa oko 600 učesnika ispred policijske stanice u Baukau koji se pretvorio u opšti napad koji je trajao više sati. Policijska stanica je devastirana kamenjem, a demonstranti su pokušavali da dopru do pripadnika ETPS i da ih linčuju, što je izbegnuto isključivo požrtvovanjem pripadnika UNPOL, mahom iz Australije koji su kordonom sprečavali ulazak u zgradu. U opštoj panici koja je zahvatila pripadnike ETPS ispaljeno je oko 1200 metaka, uglavnom kao upozorenje, u vazduh. Autor je direktni svedok i učesnik pomenutih događaja u svojstvu vojnog posmatrača UN.

${ }^{26}$ Smatralo se da iza ovih nemira stoji Kornelio Gama (Cornelio Gama), poznatiji po svom ratnom imenu El Sette (L7), nekadašnji ratni drug Xanane Gusmao. Kornelio Gama je na vrhu hijerarhije organizacije Sveta porodica (Sagrada familia). 
Neposredno posle nemira u Baukau, izbili su nemiri u glavnom gradu Diliju, koji su primorali vlast da objavi vanredno stanje. U dostupnoj literaturi ne može se naći podatak da je bilo ko imenovan kao inicijator sukoba. Isto tako, nije zabeleženo učešće milicija iz Zapadnog Timora. Policija UN, vojne snage i UNMISET u celini su bili kritikovani od domaćih vlasti za neispunjavanje dodeljenog mandata, a ETPS za nedoraslost situaciji i propuštanje prilike da se situacija smiri odgovarajućom intervencijom tokom incidenta u Baukau. ${ }^{27}$ Dobar deo demonstranata iz Baukaua je učestvovao i u nemirima u Diliju.

Bezbednosna situacija u Istočnom Timoru je bila povoljna od 2002. do 2006. godine. Taj period je protekao bez većih sukoba, ali isto tako i bez većeg napretka u rešavanju pitanja konstituisanja nacionalne policije i vojske koji su i doveli do eskalacije nasilja 2002. godine. Nakon zatvaranja 20. maja 2005, misiju UNMISET nasledila je politička misija UN u obliku kancelarije UN pod nazivom UNOTIL.

Postavlja se pitanje u kojoj je meri UNMISET mogao da odgovori na tako velike zahteve kao što je formiranje državne strukture za tako kratko vreme. Razlozi zbog kojih je direktno učešće UN u upravljanju Istočnim Timorom trajalo toliko dugo, leže u samoj prirodi države i prirodi UN kao jedne masivne, pre svega administrativne organizacije. Istočni Timor je postao samostalna država i kao takav težio je da ispolji pun suverenitet. Ujedinjene nacije, opet, nisu želele da predugo vežu svoje kapacitete na jednoj misiji. U takvoj situaciji ostale su nedovršene mnoge stvari, počevši od same privrede, preko državne administracije pa do sektora bezbednosti.

Nerešeni problemi u Istočnom Timoru su brzo isplivali na površinu. Već u januaru 2006. izbio je sukob unutar oružanih snaga koji je doveo do potpunog kolapsa sistema bezbednosti u državi i pokazao sve slabosti krhke istočnotimorske države. Ujedinjene nacije su zbog toga oformile i narednu misiju UNMIT, ${ }^{28}$ koja je pružala podršku u razvoju institucija države sve do maja 2013. godine.

Rešavanje sukoba u Istočnom Timoru, uključujući i delovanje misije UN UNMISET, predstavlja jedan od malobrojnih slučajeva sveobuhvatnog delovanja subjekata međunarodne zajednice, od stvaranja državnosti do rešavanja konflikta, ali su pri tome pokazane određene slabosti koje su, uprkos namerama, proistekle iz neodgovarajućeg rešavanja potencijalnih izvora sukoba. Istočni Timor i dalje trpi posledice koje su proistekle iz delo-

${ }^{27}$ Konferencija za štampu povodom istrage o nemirima 2002. godine sa specijalnim izaslanikom generalnog sekretara UN Kamaleš Šarmom (Kamalesh Sharma) i policijskim komesarom Sandi Peislijem (Sandi Peisley), 18. novembar 2003, Glavni štab UNMISET-a u Diliju, nezvanični transkript.

${ }^{28}$ United Nations Integrated Mission in East Timor - UNMIT. 
vanja spoljnih faktora, najviše zbog dugotrajne i neadekvatne kolonijalne vlasti. Delovanje spoljnih faktora je uzrokovalo stvaranje linija podela $u$ istočnotimorskom društvu koje se baziraju najvećim delom u odnosu na učešće u oslobodilačkoj borbi protiv okupacije Indonezije

\section{Učešće Savezne Republike Jugoslavije, odnosno Državne zajednice Srbije i Crne Gore u misiji UNMISET}

Prvo učešće pripadnika Vojske Jugoslavije posle prekida angažovanja JNA, odnosno SFRJ, u multinacionalnim operacijama 1992. godine bilo je u misiji UN u Istočnom Timoru (UNMISET). Angažovanje SRJ, a posle i Državne zajednice Srbije i Crne Gore u Istočnom Timoru počelo je u junu 2002, a završeno u junu 2004. ispunjenjem mandata misije UNMISET. Ukupno je bilo angažovano 5 oficira VJ u dve rotacije po godinu dana $\mathrm{u}$ ulozi vojnih posmatrača $U N .^{29}$

Zadaci vojnih posmatrača su bili: praćenje stanja na dodeljenoj teritoriji odgovornosti; izveštavanje nadređenom nivou; istraživanje incidenata; pomoć i saradnja sa UNPOL, mirovnim snagama i ostalim agencijama UN ili agencijama sa mandatom UN. Zadaci su realizovani kroz svakodnevne patrole, odnosno posete naseljima gde su se, kroz tipske intervjue sa relevantnim pojedincima (obično su to bili pandani nekadašnjim seoskim kmetovima, odnosno predsednici mesnih zajednica, sveštenici, predstavnici NVO, učitelji i slično) prikupljale informacije o zdravstvenoj, bezbednosnoj, ekonomskoj i obrazovnoj situaciji i pratilo ukupno stanje u dodeljenoj zoni odgovornosti. ${ }^{30}$

Vojni posmatrači Ujedinjenih nacija su bili organizovani u timove sa do tri oficira koji su izvršavali dodeljene zadatke u svojim zonama odgovornosti i bili potčinjeni višem vojnom posmatraču sektora, koji je, opet, bio potčinjen glavnom vojnom posmatraču. Za razliku od većine operacija UN (osim vojno-posmatračkih misija kao što je to UNMOGIP - United Nations Military Observer Group in India and Pakistan), organizacija vojnoposmatračke komponente UNMISET-a bila je potpuno nezavisna od organizacije mirovnih snaga. U misiji UNMIL (Liberija), na primer, viši vojni posmatrač u sektoru bio je potčinjen komandantu mirovnih snaga u sektoru i njegov izveštaj je prvo filtriran u sektorskom štabu mirovnih snaga, a onda u glavnom štabu snaga i time je bitno gubio na značaju. U UNMISET-

${ }^{29}$ Vojni posmatrači UN iz SRJ, odnosno SCG su popunili pozicije koje su ostale nepopunjene posle odlaska vojnih posmatrača iz SAD koji su napustili misiju zbog odluke SAD o neprihvatanju nadležnosti Međunarodnog krivičnog suda (ICC).

${ }^{30}$ Često se unutar misija UN nezvanično može čuti da „vojni posmatrači UN predstavljaju oči i uši misije". 
u, glavni vojni posmatrač je bio direktno potčinjen SRSG, tako da su izveštaji glavnog štaba vojnih posmatrača stizali do njega sa svim detaljima koje, možda, štab mirovnih snaga ne bi smatrao bitnim. Iz tog razloga se može reći da su vojni posmatrači UN u UNMISET-u imali bitnu i vidljivu ulogu. ${ }^{31}$ Veza sa mirovnim snagama se održavala preko oficira za vezu $u$ redovnim dnevnim aktivnostima.

Angažovanje SRJ i SCG u misiji UNMISET bilo je značajno za tadašnju državu. Time je simbolično naznačena prekretnica između „uvoza“ svetske bezbednosti i njenog „izvoza“. Učešćem u misiji UN u Istočnom Timoru završio je period kada je SRJ „ugošćavala“ misije UN na svojoj teritoriji ili bila jedna od strana u sukobu, a počeo je period aktivnog učešća $u$ održavanju svetskog mira kroz direktno učešće vojnih potencijala u misijama UN. U početku, poslove podrške angažovanju je vršila Uprava za međunarodnu vojnu saradnju Ministarstva odbrane. Međutim, vrlo brzo nakon početka učešća u misijama UN osnovan je Nacionalni centar za mirovne misije (današnji naziv je Centar za mirovne operacije Združene operativne komande Generalštaba Vojske Srbije) koji je „,regrutovao“ iskusne učesnike misija kao svoje jezgro.

Takva promena u statusu bezbednosti je zainteresovala i mnoge države partnere da svesrdno pomognu opremanje samog Centra i pruže stručnu pomoć u obuci i osposobljavanju kadra i snaga VS za učešće u narednim multinacionalnim operacijama. Time su stvorene pretpostavke za razvoj sposobnosti Vojske Srbije za izvršavanje zadataka iz druge misije Vojske (učešće u multinacionalnim operacijama).

Pored spoljnopolitičkog značaja za državu, početak angažovanja u multinacionalnim operacijama van teritorije države pozitivno je uticao na promenu profesionalnog mentaliteta, brže usvajanje novih pravila, organizacije i procedura $u$ prilagođavanju Vojske promenama u državnom uređenju i u međunarodnom bezbednosnom okruženju. $\mathrm{Na}$ individualnom nivou, učešće $u$ multinacionalnim operacijama pozitivno je uticalo na samopouzdanje i samopotvrđivanje pripadnika Vojske u multinacionalnom okruženju.

Značajnije učešće $u$ multinacionalnim operacijama je višestruko korisno $u$ političkom i vojno-stručnom pogledu. Učešćem $u$ tim operacijama doprinosi se ostvarenju ciljeva spoljne politike koji se odnose na obaveze prema međunarodnim organizacijama koje imaju ulogu očuvanja bez-

${ }^{31}$ Izveštaj tima vojnih posmatrača iz Ermere aprila 2003. o smrtnom slučaju zbog neuhranjenosti u svojoj zoni odgovornosti pokrenuo je dostavljanje humanitarne pomoći u hrani jer je kišna sezona skoro potpuno izostala i inače siromašan rod riže je potpuno podbacio. U pomenutom području nije delovala nijedna organizacija osim vojnih posmatrača UN. 
bednosti, a čiji je Republika Srbija član. Takođe, većim učešćem u međunarodnim naporima za postizanje i održavanje mira Republika Srbija može ostvariti veći uticaj (ovde se u prvom redu misli na UN i EU) pri odlučivanju o za nas bitnim pitanjima u međunarodnim organizacijama. Pored toga, uz značajnije učešće u multinacionalnim operacijama mogu se postaviti osnove za proširenje bilateralne saradnje sa državama na čijoj se teritoriji operacija izvodi.

Igor Šćepanović

\section{UNMISET: THE FIRST ENGAGEMENT OF FEDERAL REPUBLIC OF YUGOSLAVIA IN MULTINATIONAL OPERATIONS}

\section{Summary}

United Nations engagement in East Timor is one of very few examples of comprehensive actions of the international community, starting from establishment of the statehood to resolving internal conflicts. The article gives a short history of conflict in East Timor which led to the establishment of one of the UN missions in East Timor-UNMISET. ${ }^{32}$ Article briefly displays the mission's work, its results, but also points to the weaknesses and unsolved issues. Beside that, as this UN mission has some significance for Federal Republic of Yugoslavia and State Union of Serbia and Montenegro $^{33}$ having its first peacekeeping military engagement after break up of Socialistic Federal Republic of Yugoslavia, the article briefly displays engagement of its military capacities in UNMISET.

${ }^{32}$ United Nations Mission of Support in East Timor - UNMISET.

${ }^{33}$ During the engagement in UNMISET, Federal Republic of Yugoslavia changed its name into State Union of Serbia and Montenegro. 